\title{
Sleep phenotype in children with Down syndrome - altered sleep architecture and sleep-disordered breathing
}

\author{
Romana Gjergja Juraški ${ }^{1,2}$, Mirjana Turkalj2,3, Davor Plavec ${ }^{2,3}$, Boro Nogalo ${ }^{2,3}$, Ivana Marušić1, \\ Marija Miloš1, Srđan Ante Anzić4, Matilda Kovač Šižgorić ${ }^{1}$, Feodora Stipoljevev,
}

The aim of the study was to assess sleep architecture and breathing in sleep in children with Down syndrome. The study was conducted by using overnight video-polysomnography (V-PSG) in children with Down syndrome and age-matched children from the general population. Analysis of polysomnographic parameters revealed that compared to the norms of healthy age-and maturitymatched children from the general population, children with Down syndrome had significantly shorter sleep latency ( $p=0.007)$, shorter total sleep time $(p=0.004)$, lower sleep efficiency $(p=0.010)$, less NREM1 sleep phase $(p=0.0002)$, less NREM3 sleep phase $(p=0.034)$, less REM sleep ( $p=0.034$ ) in favour of more NREM2 phase but not significantly $(p=0.069)$, and spent more time awake after sleep onset ( $p=0.0002)$. Children with Down syndrome had significantly more obstructive sleep apnoeas and hypopnoeas per hour (higher obstructive sleep apnoeas and hypopnoeas index) ( $p=0.008)$, but less central sleep apnoea per hour (lower central apnoeas index) ( $(p=0.041$ ), which led to the nonsignificantly lower total apnoea-hypopnoea index ( $p=0.762)$ in children with Down syndrome. The mean and longest apnoea duration did not differ significantly between these two groups. Children with Down syndrome had a significantly lower mean and nadir oxygen saturation ( $p=0.008$ and $p=0.001$, respectively). In conclusion, the majority of respiratory complications in children with Down syndrome can be prevented by raising awareness of sleep disturbances in children with Down syndrome among their parents and health care providers and by introducing early routine V-PSG in the follow up of these children.

Key words: CHILD; DOWN SYNDROME; SLEEP APNEA SYNDROMES

\section{INTRODUCTION}

Down syndrome (DS) is the most common genetic cause of intellectual impairment, with the incidence of 1 per 691 live births (1). In industrialized world, the mean life expectancy for people with DS is approximately 60 years, thus it is important to optimize the health of children with DS through

${ }^{1}$ Department for Sleep Disorders in Children and Adolescents, Srebrnjak Children's Hospital, Zagreb, Croatia

${ }^{2}$ Osijek Faculty of Medicine, Josip Juraj Strossmayer University of Osijek, Osijek, Croatia

${ }^{3}$ Department of Pulmonology and Allergology of Preschool and School Children, Referral Centre for Clinical Paediatric Allergology of the Ministry of Health, Srebrnjak Children's Hospital, Zagreb, Croatia

${ }^{4}$ ENT Unit, Srebrnjak Children's Hospital, Zagreb, Croatia preventive measures to avoid secondary complications and provide for healthier adulthood (2).

Children with intellectual disabilities have more sleep disturbances than healthy children, such as initiating and maintaining sleep, nocturnal awakening, sleep disordered breathing (SDB) and excessive daily sleepiness $(3,4)$. Their

\footnotetext{
${ }^{5}$ Laboratory of Cytogenetics, Department of Gynaecology and Obstetrics, Sveti Duh University Hospital, Zagreb, Croatia; Faculty of Medicine, Josip Juraj Strossmayer University of Osijek, Osijek, Croatia
}

\section{Correspondence to:}

Assist. Prof. Romana Gjergja-Juraški, MD, PhD, Srebrnjak Children's Hospital, Department for Sleep Disorders in Children and Adolescents, Srebrnjak 100, HR-10000 Zagreb, Croatia, e-mail: romana.gjergja@zg.t-com.hr Primljeno/Received: 13. 11. 2019., Prihvaćeno/Accepted: 20. 11. 2019. 
specific phenotype including generalized hypotonia, underdeveloped midface with brachycephaly, narrow nasopharynx with relative airway narrowing due to large and posteriorly placed tongue and frequent lymphoid hyperplasia (5) promote their sleep problems.

Furthermore, they are prone to multiple health-related problems including congenital cardiovascular abnormalities (6), gastrointestinal problems (7), epilepsy (8), ear and hearing impairments (9), immune-related disorders (coeliac and thyroid disease and diabetes mellitus) and cancer (10).

Sleep-disordered breathing impairs gas exchange during sleep, related to airway obstruction (obstructive sleep apnoea, OSA), abnormal respiratory drive or effort (central sleep apnoea, CSA) or a mix of both conditions (11). The prevalence of OSA in DS is increased up to $63 \%$ compared to $1 \%-4 \%$ in the general population (12), making these children more vulnerable to cardiac complications of OSA, such as pulmonary and systemic hypertension and diabetes mellitus $(13,14)$.

There have been some animal model studies (15) that investigated the genotype of sleep in DS and so far some genes have been proposed as gene candidates coding for sleep phenotypes, especially genes for OSA syndrome, which should be considered as a multifactorial disease that combines genetic basis and risk factors such as obesity, central control of ventilation and craniofacial morphology (16). Many genes have been involved, from the genes that induce migration of specific cellular groups to the genes leading to structural organisation (15).

Unfortunately, sleep problems in children with DS are often underrecognized by parents, as well as by health care providers (17). Parents of developmentally delayed children are usually disturbed during the night by their children's snoring and awakenings, but when asked about it, they report disrupted sleep as an inevitable and untreatable part of their child's condition, which causes parents to renounce seeking help $(18,19)$.

Despite the facts listed above, there are limited studies analysing sleep problems in children with DS and there is still no well recognizable sleep phenotype in DS.

The aim of our study was to evaluate demographics, sleep phenotype and breathing in sleep in a cohort of children with DS, analysing overnight polysomnography in a single paediatric sleep centre.

\section{SUBJECTS AND METHODS}

We performed retrospective analysis of polysomnographic parameters of 10 children with DS referred to our children's hospital for sleep study in the past three years. Diagnosis of
TABLE 1. Demographic and clinical characteristics of children with Down syndrome included in the study

\begin{tabular}{ll}
\hline $\begin{array}{l}\text { Age (years) } \\
\text { median (range) } \\
\text { mean (SD) }\end{array}$ & $7.55(1.20-16.90)$ \\
$\begin{array}{l}\text { Female/Male } \\
\text { BMI kg/m² / ITM kg/m² } \\
\text { median (range) } \\
\text { percentile BMl for age (WHO) / median (range) (23) }\end{array}$ & $7.69(5.71)$ \\
$\begin{array}{l}\text { percentile BMI charts for Down syndrome } \\
\text { / median (range) (24) }\end{array}$ & $6 / 4$ \\
$\begin{array}{l}\text { Heart anomaly } \\
\text { ASD }\end{array}$ & $17.00(14.61-28.98)$ \\
$\quad \begin{array}{l}\text { AV canal } \\
\text { Other anomalies } \\
\text { Tracheoesophageal fistula }\end{array}$ & $60(10-90)$ \\
\hline $\begin{array}{l}\text { Frequent respiratory infections } \\
\text { GERD/ GERB }\end{array}$ & $3 / 10(30.00 \%)$ \\
\hline
\end{tabular}

$\mathrm{BMI}$ - body mass index, AV canal - atrioventricular canal,

ASD - atrial septal defect; GERD - gastro-oesophageal reflux disease

Values are expressed as absolute numbers and percentage,

unless otherwise specified/

DS was made by karyotyping and revealed regular trisomy 21 in all children. All children had been supervised by the paediatric pulmonologist/allergologist, otorhinolaryngologist and neurologist, and advised to perform overnight video polysomnography (V-PSG) due to recurrent respiratory upper tract infections or snoring. None of the children had allergic asthma, tonsillar/adenoid hypertrophy, complex heart anomaly or epilepsy. Prior to V-PSG recording, acute respiratory illnesses had also been excluded. All children underwent single night polysomnographic recording.

Overnight V-PSG included video infrared camera, microphone for vocalizations, 6-16 channel electroencephalography (EEG) according to the International 10-20 system, left and right electrooculography, surface submental electromyography, nasal pressure transducer and nasal thermistor, thoracic/abdominal plethysmography (strain gauge), electrocardiography ( $\left.2^{\text {nd }} \mid e a d\right)$, sensors for pulse and peripheral blood oxygen saturation. Recordings were started at children's usual sleep time and continued until spontaneous awakening. V-PSG was conducted in accordance with technical and digital specifications of the American Academy for Sleep Medicine (AASM) rules for technical performance and scoring of sleep (20).

We conducted the study according to ethical principles of the Helsinki Declaration. All parents gave their informed consent prior to their children's inclusion in the study.

The following polysomnographic parameters were analysed: total recording time (TRT) - time of lights out-time of lights on in minutes; total sleep time (TST) in minutes; sleep latency (SL) - time from lights out to first epoch of any sleep 
TABLE 2. Comparison of sleep architecture parameters between children with Down syndrome and norms of age- and maturitymatched healthy children from general population

\begin{tabular}{|c|c|c|c|c|}
\hline \multirow[b]{2}{*}{ TRT (min) } & $\begin{array}{l}\text { DS } \\
\text { Median (IQR) }\end{array}$ & $\begin{array}{l}\text { Norms of } \\
\text { healthy age- } \\
\text { and maturity- } \\
\text { matched } \\
\text { children } \\
\text { Median (IQR) }\end{array}$ & \multicolumn{2}{|c|}{$\begin{array}{l}\text { Mann Whitney } \\
\text { test } \\
\text { U p-value }\end{array}$} \\
\hline & $\begin{array}{l}499.00 \\
(479.00-538.00)\end{array}$ & $\begin{array}{l}527.90 \\
(507.70-539.10)\end{array}$ & 31.00 & 0.151 \\
\hline $\mathrm{SL}$ (min) & $\begin{array}{l}12.00 \\
(6.00-20.00)\end{array}$ & $\begin{array}{l}22.30 \\
(21.80-24.40)\end{array}$ & 14.50 & 0.007 \\
\hline $\mathrm{RL}(\min )$ & $\begin{array}{l}132.00 \\
(79.00-198.00)\end{array}$ & $\begin{array}{l}135.45 \\
(100.20-155.10)\end{array}$ & 47.00 & 0.820 \\
\hline TST (min) & $\begin{array}{l}425.50 \\
(413.00-465.00)\end{array}$ & $\begin{array}{l}489.25 \\
(481.50-512.20)\end{array}$ & 12.00 & 0.004 \\
\hline SE (\%) & $\begin{array}{l}85.27 \\
(83.13-91.40)\end{array}$ & $\begin{array}{l}94.53 \\
(92.31-95.01)\end{array}$ & 16.00 & 0.010 \\
\hline NREM1 (\%) & $\begin{array}{l}2.00 \\
(1.60-2.60)\end{array}$ & $\begin{array}{l}7.00 \\
(6.70-7.30)\end{array}$ & 0.00 & 0.0002 \\
\hline NREM2 (\%) & $\begin{array}{l}47.85 \\
(36.30-53.70)\end{array}$ & $\begin{array}{l}38.60 \\
(31.10-42.60)\end{array}$ & 26.00 & 0.069 \\
\hline NREM3 (\%) & $\begin{array}{l}28.10 \\
(23.80-30.40)\end{array}$ & $\begin{array}{l}31.90 \\
(28.90 \text { to } 34.90)\end{array}$ & 22.00 & 0.034 \\
\hline REM (\%) & $\begin{array}{l}17.65 \\
(12.90-21.40)\end{array}$ & $\begin{array}{l}21.10 \\
(20.30-23.20)\end{array}$ & 22.00 & 0.034 \\
\hline TWT (min) & $\begin{array}{l}51.50 \\
(28.00-83.00)\end{array}$ & $\begin{array}{l}5.15 \\
(5.10-7.70)\end{array}$ & 0.00 & 0.0002 \\
\hline $\mathrm{Arl}$ & $\begin{array}{l}14.50 \\
(7.00-19.00)\end{array}$ & $\begin{array}{l}1.10 \\
(1.10-1.30)\end{array}$ & 1.00 & 0.0002 \\
\hline $\mathrm{AHI} / \mathrm{h}$ & $\begin{array}{l}0.57 \\
(0.13-1.66)\end{array}$ & $\begin{array}{l}0.65 \\
(0.40-1.50)\end{array}$ & 46.00 & 0.762 \\
\hline $\mathrm{OAHI} / \mathrm{h}$ & $\begin{array}{l}0.31 \\
(0.00-0.61)\end{array}$ & $\begin{array}{l}0.00 \\
(0.00-0.00)\end{array}$ & 20.00 & 0.008 \\
\hline $\mathrm{CAl} / \mathrm{h}$ & $\begin{array}{l}0.17 \\
(0.00-0.57)\end{array}$ & $\begin{array}{l}0.65 \\
(0.40-1.50)\end{array}$ & 23.00 & 0.041 \\
\hline $\begin{array}{l}\text { Mean apnoea } \\
\text { duration (s) }\end{array}$ & $\begin{array}{l}9.50 \\
(8.00-11.00)\end{array}$ & $\begin{array}{l}10.50 \\
(8.80-10.60)\end{array}$ & 48.00 & 0.880 \\
\hline $\begin{array}{l}\text { Longest apnoea } \\
\text { duration (s) }\end{array}$ & $\begin{array}{l}11.00 \\
(9.00-16.00)\end{array}$ & $\begin{array}{l}13.15 \\
(12.50-15.50)\end{array}$ & 34.00 & 0.226 \\
\hline $\begin{array}{l}\text { Mean satO2 } \\
(\%)\end{array}$ & $\begin{array}{l}96.00 \\
(95.00-96.00)\end{array}$ & $\begin{array}{l}98.00 \\
(98.00-98.00)\end{array}$ & 16.00 & 0.008 \\
\hline $\begin{array}{l}\text { Nadir satO2 } \\
(\%)\end{array}$ & $\begin{array}{l}87.00 \\
(85.00-90.00)\end{array}$ & $\begin{array}{l}93.00 \\
(92.00-93.50)\end{array}$ & 4.00 & 0.001 \\
\hline
\end{tabular}

AHI: apnoea-hypopnoea index, Arl: arousal index, ASD: atrial septal defect, AV canal: atrioventricular canal, BMI: body mass index, CAl: central apnoeas index, CSA: central sleep apnoea, DS: Down syndrome, GERD: gastro-oesophageal reflux disease, $\mathrm{h}$ - hour, IQR: interquartile ratio, min - minute, NREM1: non-rapid eye movement sleep phase 1 NREM2: non-rapid eye movement sleep phase 2, NREM3: non-rapid eye movement sleep phase 3, REM: rapid eye movement sleep phase, OAHI: obstructive sleep apnoeas and hypopnoeas index, RL: REM latency, SL: sleep latency, SE: sleep efficiency, s: second, satO : blood oxygen saturation, TRT: total recording time, TST: total sleep time, TWT: total wake time, V-PSG: video-polysomnography, WHO: World Health Organisation. in minutes; REM latency (RL) - sleep onset to first epoch of stage REM in minutes; total wake time (TWT) - TRT-TST-SL in minutes; percent sleep efficiency (SE) - TST/TRT x100; percent of TST in each sleep stage - time in each stage/TST x100; arousal index (Arl) per hour - number of arousals x60/ TST; Obstructive Apnea-Hypopnea Index (OAHI) per hournumber of obstructive apnoeas and hypopnoeas x60/TST; Central Apnea Index (CAl) per hour - number of central apnoeas x60/ TST; Total Apnea-Hypopnea index (AHI) per hour - OAHI + CAl; duration of obstructive and central apnoeas in seconds; and percentage of mean and minimum oxygen saturation.

We analysed clinical data of children with DS (Table 1), and compared their polysomnographic parameters (Table 2) to appropriate age- and maturity-matched norms of healthy children from the general population $(21,22)$.

\section{Statistics}

Statistical analysis of quantitative data was performed using mean and standard deviation ( $\bar{x} \pm S D$ ), or in case of nonparametric distribution using median and interquartile range. Categorical data were expressed as absolute frequencies and percentages (\%). Comparisons between the two groups were performed using the Mann-Whitney $U$ test. The $p$ values less than 0.05 were considered statistically significant. Statistical analysis was performed using the MedCalc Statistical Software for Windows, version 17.6 (MedCalc Software, Ostend, Belgium; http://www.medcalc.org; 2017).

\section{RESULTS}

\section{Demographics}

The median age of ten children (six girls and four boys) with DS in our cohort was 7.55 (range 1.20-16.90) years, median body mass index (BMI) 17 (range 12.35-28.98) kg/m². According to the WHO BMI-for-age charts designed for the general paediatric population (23), the median BMI-for-age percentile in children with DS was $90^{\text {th }}$ (range 15-99) as opposed to the median $60^{\text {th }}$ percentile (range 10-90) BMI-for-age according the US charts for children with DS (24).

Most of the children with DS had frequent respiratory infections (70\%). One child had corrected trachea-oesophageal fistula. Most of the children in our cohort had no heart anomaly (70\%). One child was diagnosed with gastroesophageal reflux disease (GERD).

\section{Sleep Architecture}

Analysis of polysomnographic parameters revealed that children with DS, compared to the norms of healthy age- 
and maturity-matched children, had significantly shorter sleep latency $(S L)(p=0.007)$, shorter total sleep time (TST) $(p=0.004)$, lower sleep efficiency (SE) $(p=0.010)$, less NREM1 sleep phase $(p=0.0002)$, less NREM3 sleep phase $(p=0.034)$, and less REM sleep ( $p=0.034$ ) (in favour of more NREM2 phase but not significantly, $p=0.069)$. Children with DS spent more time awake after sleep onset, compared to the norms of healthy children $(p=0.0002)$.

\section{Breathing in sleep}

Children with DS had significantly more obstructive sleep apnoeas per hour (higher OAHI) $(p=0.008)$, but less central sleep apnoea per hour (lower CAI) $(p=0.041)$, which led to the nonsignificantly lower total $\mathrm{AHI}(\mathrm{p}=0.762)$ in children with DS. The mean and longest apnoea duration did not differ significantly between these two groups. Children with DS had significantly lower mean and nadir oxygen saturation ( $p=0.008$ and $p=0.001$, respectively).

\section{DISCUSSION}

In our study, we evaluated demographics, sleep phenotype and breathing in sleep in a cohort of children with DS, using overnight polysomnography in a single paediatric sleep centre.

\section{Demographics}

The median $90^{\text {th }}$ percentile BMI-for-age (range $15^{\text {th }}-99^{\text {th }}$ ) in children with DS according to the WHO charts (23) versus median $60^{\text {th }}$ percentile (range $10^{\text {th }}-90^{\text {th }}$ ) according to the US charts for children with DS (24) indicated that the DS specific charts classified less children as obese compared to the charts for children from the general population (25). As children with DS are at risk of obesity and obstructive sleep apnoea syndrome (OSAS), referral to the DS specific charts could lead to delay in weight management and support in early childhood (26). Related to our result of frequent respiratory infections in children with DS, an Australian study (27) found that DS children were hospitalized five times more often than the general paediatric population. The most common cause for hospital admissions were respiratory tract (most commonly pneumonia and bronchiolitis) and ear/hearing conditions, accounting for one quarter of all admissions.

\section{Sleep architecture}

Our study demonstrated that DS children had significantly shorter SL, shorter TST and lower SE. We also recorded less NREM1 sleep, less NREM3 sleep and less REM sleep. In con- trast to some other studies (2), we found decreased NREM3 phase, which could point to decreased restorative capacity frequently found in children with cognitive impairment and additionally could be a consequence of chronic sleep deprivation and disruption. Decreased proportion of REM sleep is a constant result in the paucity of validated data analysing sleep problems in children with DS $(2,28)$. In this sense, alteration of NREM structure associated with the reduction in REM sleep may be considered a distinctive feature of intellectual disability, bearing in mind their influence on learning, memory and behaviour (2). Children with DS spent more time awake after sleep onset and had higher Arl, irrespective of apnoea episodes, indicating sleep fragmentation. The study by Fernandez and Edgin (29), taking into account the high prevalence of OSAS and Alzheimer disease in DS, proposed that sleep disruption could predispose individuals with DS to earlier onset or faster deterioration with dementia. In this sense, improving sleep architecture in children with DS could be an overlooked way to improve cognitive outcomes in this population.

An interesting finding in our study was shorter sleep latency, which could be impacted by excessive daytime sleepiness reported by their parents. Furthermore, behaviour and learning problems stemming from sleep disruption in these children may be overlooked and falsely attributed to their limited intellectual abilities (30).

\section{Breathing in sleep}

In our study, DS children had a significantly higher OAHI but lower CAl, which led to the nonsignificantly lower total AHI. The mean and longest apnoea duration did not differ significantly between these two groups. This is in accordance with other studies showing obstructive apnoea as the most prevalent type of apnoea in DS (31), which could be related to their face and neck phenotypic characteristics.

There is evidence that snoring, struggling to breathe at night and even obesity are all unreliable parameters to identify SDB in children with DS (32-34). This is one of the reasons why polysomnography should be performed. It may be that GERD symptoms may mimic those of SDB, prompting referral for polysomnography. It is still inconclusive whether GERD is more often related to SDB (32).

Since we did not include children with adenotonsillar hypertrophy, their OAHI was not influenced by tonsils and adenoids, confirming that OSAS is a multifactorial syndrome and adenotonsillectomy frequently has no positive effect on OSAS in children with DS. Children with DS and OSA undergoing tonsillectomy could experience improvements in respiratory event frequency and gas exchange, but half of them still have moderate to severe residual OSA (35). 
We also paid attention to marked sleep-associated oxygen desaturation in our DS children. While some authors explain this fact by different autonomic control of ventilation in these children and consider it a normal variant with no need for intervention other than close monitoring for pulmonary hypertension (36), we think that their marked generalized hypotonia may be an additional unfavourable factor for desaturation in sleep.

Our polysomnographic results supported the recommendation of the American Academy of Pediatric Health Supervision for Children with Down Syndrome for all children with DS to receive polysomnography by the age of four (19). However, the findings of this study highlight the limitations of screening with polysomnography at a single time point and suggest that further longitudinal studies are needed to better identify clinical correlates in different age groups and SDB dynamics over time. Repeated sleep studies could be performed at several targeted ages to diagnose SDB. Repeated sleep studies are needed particularly after ENT treatment interventions (37). Identification of SDB is crucial in this population and could decrease or prevent its significant associated comorbidity and acute hospital admissions.

At each well-child visit, health care providers should discuss with the parents of DS children the symptoms of sleep disorders such as heavy breathing, snoring, restless sleep, uncommon sleep positions, frequent night awakening, excessive daytime sleepiness, breathing pauses and behaviour problems. Parents should be educated that poor sleep quality and altered sleep structure may further impair cognitive, behavioural and physical growth of their children with DS (19).

In conclusion, promoting the importance of routine sleep study early in childhood and addressing the awareness of sleep problems among health care providers and parents of children with DS, we can help optimization of health in children with DS, providing their healthier and longer adulthood.

\section{ACKNOWLEDGEMENT}

We thank Nataša Nenadić Baranašić, MD, PhD and Darija Ordulj Aničić, Nurse Graduate, for their efforts while working at our Department for Sleep Disorders.

\section{REFERENCES}

1. Parker SE, Mai CT, Canfield MA, Rickard R, Wang Y, Meyer RE, Anderson P, et al. Updated national birth prevalence estimates for selected birth defects in the United States, 2004-2006. Birth Defects Res A Clin Mol Teratol. 2010;88:1008-16.

2. Nisbet LC, Phillips NN, Hoban TF, O'Brien LM. Characterization of a sleep architectural phenotype in children with Down syndrome. Sleep Breath. 2015;19:1065-71. doi: 10.1007/s11325-014-1094-6.

3. Didden R, Korzillius H, van Aperlo B, Overloop C, de Vries M. Sleep problems and daytime problem behaviors in children with intellectual disability. J Intellect Dev Disabl. 2002;46:537-47.
4. Krakowiak P, Goodlin-Jones B, Hertz-Picciotto I, Croen L, Hansen R. Sleep problems in children with autism spectrum disorders, developmental delays, and typical development: a population based study. J Sleep Res. 2008;17:197-206.

5. Donnelly LF, Shott SR, LaRose CR, et al. Causes of persistent obstructive sleep apnea despite previous tonsillectomy and adenoidectomy in children with Down syndrome as depicted on static and dynamic MRI. Am J Roentgenol. 2004;183:175-81

6. Irving CA, Chaudhari MP. Cardiovascular abnormalities in Down's syndrome: spectrum, management and survival over 22 years. Arch Dis Child. 2012;97:326-30.

7. Cleves MA, Hobbs CA, Cleves PA, Tilford JM, Bird TM. Congenital defects among liveborn infants with Down syndrome. Birth Defects Res A Clin Mol Teratol. 2007;79:657-63.

8. Elia M, Musumeci SA, Ferri R, Ayala GF. Chromosome abnormalities and epilepsy. Epilepsia. 2001;42(Suppl 1):24-7.

9. Määttä T, Kaski M, Taanila A, livanainen M. Sensory impairments and health concerns related to the degree of intellectual disability in people with Down syndrome. Downs Syndr Res Pract. 2006;11:78-83.

10. Goldacre MJ, Wotton CJ, Seagroatt V, Yeates D. Cancers and immune related diseases associated with Down's syndrome: a record linkage study. Arch Dis Child. 2004;89:1014-7.

11. Marcus C. Sleep-disordered breathing in children. AJRCCM. 2001;164:16-30.

12. Rosen D. Management of obstructive sleep apnea associated with Down syndrome and other craniofacial dysmorphologies. Curr Opin Pulm Med. 2011;17:431-6. doi: 10.1097/MCP.0b013e32834ba9c0.

13. Loughlin GM, Wynne JW, Victorica BE. Sleep apnea as a possible cause of pulmonary hypertension in Down syndrome. J Pediatr. 1981;98:435-7.

14. Punjabi NM, Shahar E, Redline $S$, et al. Sleep-disordered breathing, glucose intolerance, and insulin resistance: the Sleep Heart Health Study. Am J Epidemiol. 2004;160:521-30.

15. Casale M, Pappacena M, Rinaldi V, Bressi F, Baptista P, Salvinelli F. Obstructive sleep apnea syndrome: from phenotype to genetic basis. Curr Genom. 2009;10:119-26.

16. Taheri S, Magnot E. Genetics of sleep disorders. Lancet Neurol. 2002;1: 242-50.

17. Shot SR, Amin R, Chini B, Heubi C, Hotze S, Akers R. Obstructive sleep apnea. Should all children with Down syndrome be tested? Arch Otolaryngol Head Neck Surg. 2006;132:432-6.

18. Robinson AM, Richdale AL. Sleep problems in children with an intellectual disability: parental perceptions of sleep problems, and views of treatment effectiveness. Child Care Health Dev. 2004;30:139-50.

19. Bull MJ. Health supervision for children with Down syndrome. Pediatrics. 2011;128:393-406.

20. Berry RB, Brooks R, Gamaldo CE, Harding SM, Lloyd RM, Marcus CL, Vaughn BV; for the American Academy of Sleep Medicine. The AASM Manual for the Scoring of Sleep and Associated Events: Rules, Terminology and Technical Specifications, Version 2.3. www.aasmnet.org. Darien, Illinois: American Academy of Sleep Medicine, 2016.

21. Scholle S, Beyer U, Bernhard M, Eichholz S, Erler T, Graness P, GoldmannSchnalke B, Heisch K, Kirchhoff F, Klementz K, Koch G, Kramer A, Schmidtlein C, Schneider B, Walther B, Wiater A, Scholle HC. Normative values of polysomnographic parameters in childhood and adolescence: quantitative sleep parameters. Sleep Med. 2011;12:542-9. doi: 10.1016/j. sleep.2010.11.011.

22. Scholle S, Wiater A, Scholle HC. Normative values of polysomnographic parameters in childhood and adolescence: cardiorespiratory parameters. Sleep Med. 2011;12:988-96. doi: 10.1016/j.sleep.2011.05.006.

23. WHO Child Growth Standards. http://www.who.int/childgrowth/standards/ bmi_for_age/en/

24. Zemel BS, Pipan M, Stallings VA, Hall W, Schadt K, Freedman DS, Thorpe P. Growth charts for children with Down syndrome in the United States. Pediatrics. 2015;136:e1204-11. doi: 10.1542/peds.2015-1652. 
25. Ogden CL, Kuczmarski RJ, Flegal KM, Mei Z, Guo S, Wei R, Grummer-Strawn LM, Curtin LR, Roche AF, Johnson CL. CDC 2000 growth charts for the United States: improvements to the 1977 National Center for Health Statistics version. Pediatrics. 2002;109:45-60.

26. Basil JS, Santoro SL, Martin LJ, Healy KW, Chini BA, Saal HM. Retrospective study of obesity in children with Down syndrome. J Pediatr. 2016;173:1438. doi: 10.1016/j.jpeds.2016.02.046

27. Fitzgerald P, Leonard H, Pikora TJ, Bourke J, Hammond G. Hospital admissions in children with Down syndrome: experience of a populationbased cohort followed from birth. PloS One. 2013;8:e70401. doi: 10.1371/ journal.pone.0070401. eCollection 2013.

28. Dyken ME, Lin-Dyken DC, Poulton S, Zimmerman MB, Sedars E. Prospective polysomnographic analysis of obstructive sleep apnea in Down syndrome. Arch Pediatr Adolesc Med. 2003;157:655-60.

29. Fernandez F, Edgin JO. Poor sleep as a precursor to congitive decline in Down syndrome: a hypothesis. J Alzheimers Dis Parkinsonism. 2013;3:124. doi: 10.4172/2161-0460.1000124

30. Levanon A, Tarasiuk A, Tal A. Sleep characteristics in children with Down syndrome. J Pediatr. 1999;134:755-60.

31. Lin SC, Davey MJ; Horne RSC, Nixon GM. Screening for obstructive sleep apnea in children with Down syndrome. J Pediatr. 2014;165:117-22.
32. Nehme J, LaBerge R, Pothos M, Barrowman N, Hoey L, Monsour A, Kukko M, Katz SL. Predicting the presence of sleep-disordered breathing in children with Down syndrome. Sleep Med. 2017;36:104-8. doi: 10.1016/j. sleep.2017.03.032

33. Miguel-Diez J, Villa-Asensi JR, Alvarez-Sala JL. Prevalence of sleepdisordered breathing in children with Down syndrome: polygraphic findings in 108 children. Sleep. 2003;26:1006-9.

34. Hill CM, Evans $\mathrm{HJ}$, Elphick $\mathrm{H}$, et al. Prevalence and predictors of obstructive sleep apnoea in young children with Down syndrome. Sleep Med. 2016;27e28:99e106.

35. Ingram DG, Ruiz AG, Gao D, Friedman NR. Success of tonsillectomy for obstructive sleep apnea in children with Down syndrome. J Clin Sleep Med. 2017 15;13:975-980. doi: 10.5664/jcsm.6698.

36. Wong W, Rosen D. Isolated mild sleep-associated hypoventilation in children with Down syndrome. Arch Dis Child. 2017. doi: 10.1136/ archdischild-2016-311694.

37. Waters KA, Castro C, Chawla J. The spectrum of obstructive sleep apnea in infants and children with Down syndrome. Int J Pediatr Otorhinolaryngol. 2019;1:109763. doi: 10.1016/j.jporl.2019.109763. [Epub ahead of print]

\section{Fenotip spavanja u djece s Downovim sindromom - izmijenjena arhitektura spavanja i poremećeno disanje}

\section{u snu}

Romana Gjergja Juraški, Mirjana Turkalj, Davor Plavec, Boro Nogalo, Ivana Marušić, Marija Miloš, Srđan Ante Anzić, Matilda Kovač Šižgorić, Feodora Stipoljev

Cilj: Istražiti arhitektoniku spavanja i disanja tijekom sna u djece s Downovim sindromom. Metode: Cjelonoćna videopolisomnografija (V-PSG) u skupini djece s Downovim sindromom i u onoj iz opće populacije odgovarajuće dobi i zrelosti. Rezultat: Analiza polisomnografskih parametara pokazala je da djeca s Downovim sindromom, u usporedbi s normativima u zdrave djece u općoj populaciji, odgovarajuće dobi i zrelosti, imaju značajno kraću latenciju spavanja (SL) p=0,007, kraće ukupno vrijeme spavanja (TST) $p=0,004$, nižu efikasnost spavanja (SE) p=0,010, manje NREM1 faze spavanja $p=0,0002$, manje NREM3 faze spavanja $p=0,034$, manje REM spavanja $p=0,034$ (na račun više površnog NREM2 spavanja, ali ne statistički značajno, $p=0,069$ ) i da provode više vremena budni nakon započimanja spavanja $(p=0,0002)$. Djeca s Downovim sindromom imaju značajno više opstruktivnih apneja i hipopneja po satu spavanja (viši OAHI) p=0,008, ali imaju manje centralnih apneja po satu spavanja (niži CAl) p=0,041, što pridonosi statistički neznačajno nižem ukupnom AHI-u $(p=0,762)$ u djece s Downovim sindromom. Prosječno i najdulje trajanje apneja nije se značajno razlikovalo između dviju skupina. Djeca s Downovim sindromom su imala značajno niže i prosječne i nadir saturacije kisika ( $p=0,008$ i $p=0,001)$. Zaključak: Možemo prevenirati većinu respiratornih komplikacija u djece s Downovim sindromom podizanjem svjesnosti njihovih roditelja o poremećajima spavanja u te djece, ali i zdravstvenih djelatnika, te uključivanjem rutinske cjelonoćne videopolisomnografije u njihovo praćenje. 